\title{
ANALIZE ZAVISNOSTI VISINA PADAVINA OD NADMORSKIH VISINA NA PROSTORU SRBIJE
}

Zoran M.Radić

Dragutin Pavlović ${ }^{1}$

УДК: 551.577 .5

DOI:10.14415/konferencijaGFS 2015.079

Rezime: Ubrzani razvoj brzine procesuiranja i kapaciteta memorija računara omogućili su uvođenje hidroloških modela sa distribuiranim parametrima i proračune prostornih karakteristika u okviru GIS-orijentisanih modela. Pri modeliranju se često iz literature preuzimaju određene relacije bez prethodne provere na podacima sa konkretnog sliva. Padavine predstavljaju glavne ulaze hidroloških modela, pa su pouzdane analize prostornog $i$ visinskog rasporeda kiša od presudnog uticaja na krajnje rezultate.

Cilj ovog rada je da utvrdi da li je na prostoru Srbije opravdano vršiti korekcije padavina u funkciji promena nadmorske visine. Analize su obuhvatile podatke sa 26 glavnih meteoroloških stanica koje verno reprezentuju visinske odnose na prostoru čitave Srbije. U analize su uključeni podaci o prosečnim godišnjim padavinama, statistike (srednje vrednosti, koeficijenti varijacije i koeficijenti asimetrije) jakih kiša kratkih trajanja, kao i računske vrednosti jakih kiša povratnog perioda 100 godina (verovatnoće pojave 1\%) za trajanja u rasponu od 10 minuta do 1 dan. Pored toga ispitana je $i$ zavisnost prosečnih godišnjih padavina sa računskim jednodnevnim padavinama.

Zaključeno je da globalno posmatrano na prostoru Srbije nema opravdanja da se uvode korekcije padavina sa nadmorskom visinom, a preporučeno da se kod modeliranja, korišćenjem maksimalno raspoloživih lokalnih podataka merenja, karakter veze ispita $i$ utvrde relacije na svakom konkretnom slivu.

Кључне речи: Hidrologija, jake kiše,regionalne analize

\section{UVODNA RAZMATRANJA}

Za hidrološku praksu statističke obrade jakih kiša su jedan od ključnih elemenata jer se na bazi njih, primenom modela za transformaciju padavina u oticaj, određuju merodavni proticaji za dimenzionisanje hidrotehničkih objekata (kišna kanalizacija, propusti, itd) i-ili merodavni poplavni talasi za dimenzionisanje preliva, retenzionog prostora za prihvatanje i transformaciju poplavnih talasa, isl.

\footnotetext{
${ }^{1}$ Građevinski fakultet Univerziteta u Beogradu, zradic@grf.bg.ac.rs
} 
International conference

Contemporary achievements in civil engineering 24. April 2015. Subotica, SERBIA

Računske kiše, kao ulazi modela za simulaciju oticaja, podjednako se mogu koristiti i na velikim i na malim slivovima. Na urbanim slivovima i manjim prirodnim slivovima bujičnog karaktera, gde su vremena koncentracija kratka, od interesa su jake kiše kratkih trajanja (reda veličine minuta i časova), dok su za velike slivove od interesa kiše dugih trajanja (ponekad čak i višednevne kiše).

U zadnje vreme, uvođenjem distribuiranih modela oticaja sve je učestalija praksa da se visine padavina unutar sliva koriguju u funkciji nadmorskih visina, a isti pristup pokušava se uvesti i u praksu određivanja merodavnih jakih kiša kratkog ukoliko se one određuju na bazi lokalnih analiza verovatnoće pojave dnevnih maksimuma u kombinaciji sa redukcionim krivama jakih kiša kraćih trajanja trajanja (Prohaska i sar., 2014).

U prvom od navedenih slučajeva pretpostavlja se da za bilo koje padavine (kišne epizode različitih trajanja) postoji isti karakter (gradijent) promena padavina sa nadmorskom visinom kao što postoji i za prosečne (višegodišnje) padavine. Ne retko gradijent tih promena se prethodno i ne proverava na konkretnom slivu, nego se a priori usvajaju „gradijenti iz literature“.

U drugom slučaju pretpostavlja se da isti gradijent promena padavina sa nadmorskom visinom važi i za prosečne i ekstremne padavine ${ }^{2}$.

Cilj ovog rada je provera navedenih pretpostavki, a obuhvata analize karaktera promena prosečnih i ekstremnih padavina u funkciji nadmorske visine na prostoru Srbije. Sve analize su sprovedene na bazi podataka sa 26 lokacija glavnih meteoroloških stanica (GMS) i sa podacima od početka rada pluviografa zaključno sa 2006 godinom, za koje se pretpostavlja da dovoljno verno reprezentuju i prostorne i visinske karakteristike Republike Srbije. Svi podaci preuzeti su iz Vodoprivredne Osnove Republike Srbije (VOS-2009).

\section{VEZE PADAVINA SA NADMORSKOM VISINOM}

Opšte je poznato da usled uticaja orografije prosečne padavine rastu sa nadmorskom visinom, a specijalna merenja obavljena u Francuskoj (projekat TPG) pokazala su da isto važi i za intenzitete jakih kiše. Međutim, te analize su obuhvatile „baterije pluviografa“ koje su postavljene preko planinskih lanaca tako sa su obuhvaćene visinske razlike reda veličine oko $4500 \mathrm{~m}$. Pitanje je da li isto važi i za prostor Srbije koja je u delu severno od Dunava (izuzev Vršačkog brega) skoro ravna i gde je u brdovitom delu južno od Dunava samo jedna kišomerna stanica (,Kopaonik“ sa H=1710 mnm) iznad nadmorske visine od $1300 \mathrm{mnm}$.

U okviru Vodoprivredne osnove Srbije, gde su obrađivani podaci sa 437 kišomernih stanica, nisu detaljno prikazane zavisnosti prosečnih i ekstremnih padavina u funkciji

\footnotetext{
${ }^{2}$ Do tog saznanja došao je i prvi autor ovog rada poredići izohijte prosečnih godišnjih padavina i izohijetske situacije tokom negoliko najvećih kišnih epizoda u slivu Gornje Drine gde postoje veoma velike visinske razlike između lokacija pojedinih kišomera. Međutim, kasnijim detaljnim analizama sa dugim serijama dnevnih padavina na velikom broju lokacija opšta zakonitost nije potvrđena, a analize velikog broja radarskih planšeta za najveće opažene kišne talase su pokazale da su za genezu poplavnih talasa mnogo značajniji elementi koji se odnose na prostor sliva zahvaćen kišom kao i dinamika kretanja kišnih talasa po slivu. Na žalost, (prem da je prostor Srbije dobro pokriven mrežom savremenih meteoroloških radara), ovim elementima se ne poklanja nikakva pažnja.
}

\section{2}


nadmorske visine, a nije dat ni pregled zastupljenosti broja stanica po nadmorskim visinama. Jedino je navedeno da se u planininskim regionima vertikalni gradijent padavina kreće u rasponu $25-40 \mathrm{~mm} / 100 \mathrm{~m}$.

Našim analizama ustanovljeno je da od 437 analiziranih samo $1 \%$ kišomernih stanica je sa najnižim kotama $(\mathrm{H}<80 \mathrm{mnm})$, a samo 4\% sa kotama iznad $1000 \mathrm{mnm}$ (pri čemu samo GMS „Kopaonik“ ima kotu iznad $1300 \mathrm{mnm}$ ). U rasponu $\mathrm{H}=500-1000 \mathrm{mnm}$ nalazi se $17 \%$ kišomernih stanica, dok su sve ostale, (ukupno $78 \%$ stanica), na nadmorskim visinama u rasponu $\mathrm{H}=80-500 \mathrm{mnm}$. Očigledno je da raspored kišomernih stanica u Srbiji verno odražava zastupljenost nadmorskih visina i visinskiih lokacija naselja , ali je pitanje da li to omogućava da se ustanove uticaji promena nadmorskih visina lokacija kišomernih stanica na visine padavina.

Opšte je poznato da se kvalitet regresije (ukoliko ne postoji absolutna funkcionalna zavisnost) smanjuje sa povećanjem broja tačaka, što dozvoljava da se globalni karakter veza padavina sa nadmorskom visinom ispita na poduzorku od 26 tačaka, odnosno na osnovu podataka za lokacije glavnih meteoroloških stanica (GMS).

Pregled nadmorskih visina za analizirane lokacije pluviografa u okviru GMS prikazan je na Slici 1 . Sa Slike 1 se vidi da postoji dovoljno veliki raspon obuhvaćenih nadmorskih visina, kao i to da njihova zastupljenost verno reprodukuje globalnu zastupljenost na prostoru čitave Srbije.

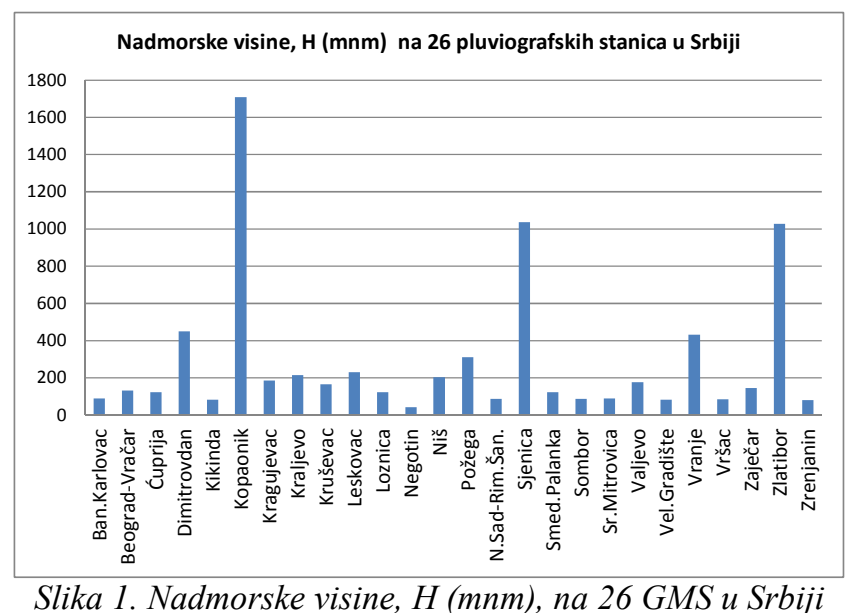

Za višegodišnje proseke (period 1946-2006) i padavine sa 25 lokacija pluviografa na lokacijama GMS regresiona veza sa nadmorskom visinom prikazana je na Slici 2. 


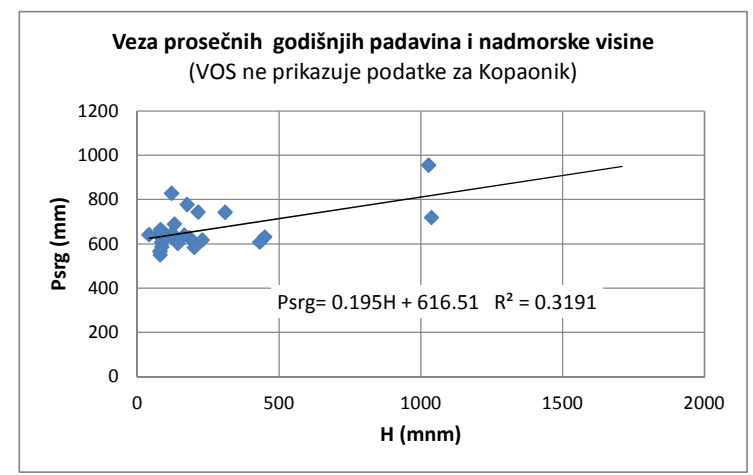

Slika 2. Veza prosečnih godišnjih padavina i nadmorske visine

$\mathrm{Na}$ prvi pogled izgleda da se prosečne godišnje padavine povećavaju (,rastu“) sa nadmorskom visinom (kao što se očekuje), kao i to da je prosečan gradijent oko $20 \mathrm{~mm} / 100 \mathrm{~m}$. Međutim kvalitet regresione veze porasta padavina sa nadmorskom visinom, (mereno koeficijentom determinacije koji predstavlja procenat objašnjenih varijacija), nije zadovoljavajući za ozbiljne hidrološke primene.

To postaje još jasnije ukoliko se detaljnije analiziraju karakteristične vrednosti:

- Za najnižu lokaciju od razmatranih, H=46 mnm („Negotin“) Psg= $640 \mathrm{~mm} /$ god, a za 8 lokacija u kojima je $\mathrm{H}=80-89 \mathrm{mnm}$ prosečne vrednosti se kreću u rasponu Psg=549-649 mm/god

- Za dve lokacije sa istim nadmorskim visinama $\mathrm{H}=121 \mathrm{mnm}$ (,Smederevska Palanka“ i „Loznica“), izmerene vrednosti su u rasponu Psg=632-828 mm/god, što daje razliku od skoro $200 \mathrm{~mm}(\mathrm{dP}=196 \mathrm{~mm})$

- $\quad$ Za dve najviše lokacije, „Sjenica“ (H=1038 mnm) i „Zlatibor“ (H=1028 mmm), čije vrednosti praktično usmeravaju liniju tendencije porasta i za koje je $\mathrm{dH}=10 \mathrm{~m}$ gradijent ,porasta“ padavina je negativan $(\mathrm{dP}=719-955=-236 \mathrm{~mm})$.

Na osnovu prethodnog može se zaključiti:

- Da na prostoru Srbije nema opravdanja da se prosečne padavine koriguju u funkciji nadmorske visine, a još manje je opravdano da se nepouzdana veza određena za višegodišnje proseke primenjuje za prostornu distribuciju padavina kraćih trajanja.

Drugim rečima, ukoliko se pri modeliranju oticaja želi uvesti nelinearna prostorna distribucija padavina (koja uključuje vezu sa nadmorskom visinom), takva zavisnost se prethodno mora povrditi na bazi podataka merenih na konkretnom slivu.

Zadnje formulisani zaključak potvrđuju i podaci o padavinama zabeleženih tokom katastrofalnih poplava (Lit.5). Tako su, npr. tokom katastrofalnih poplava koje su se 1989. godine desile u slivu Radaljske reke (desna pritoka reke Drine), na 7 kišomernih stanica zabeležene sledeće padavine (kiša je trajala oko 6 sati):

TABELA 1. Padavine registrovane 21.08. 1989 godine koje su izazvale poplave u slivu Radaljske reke (redosled kišomernih stanica nadmorskim visinama)

\begin{tabular}{|l|l|l|l|l|l|l|l|}
\hline Kiš.St. & Loznica & M.Zvornik & B.Koviljača & D.Borina & Krupanj & Dvorska & Planina \\
\hline $\mathrm{H}(\mathrm{mnm})$ & 121 & 160 & 180 & 200 & 280 & 300 & 560 \\
\hline $\mathrm{P}(\mathrm{mm})$ & 77,1 & 46,5 & 41 & 16,8 & 10,8 & 1,2 & 102,5 \\
\hline
\end{tabular}

\section{4}


Међународна конференција

Савремена достигнућа у грађевинарству 24. април 2015. Суботица, СРБИЈА

Prema podacima iz Tabele 1, tačno je da su najveće padavine izmerene na k.s."Planina" sa najvećom nadmorskom visinom, ali kod svih ostalih 6 k.s. vidi se da postaji značajno opadanje padavina sa porastom nadmorske visine ${ }^{3}$.

U okviru Lit.5 prikazano je više radova koji objašnjavaju klimatološke i dinamičke karakteristike u atmosferi koje dovode do pojave intenzivnih padavina, zatim brojne primere konkretnih meteoroloških uslova koji su doveli do pojava katastrofalnih poplava, kao i seriju radova o mogućnostima najave atmosferskih elementarnih nepogoda korišćenjem meteoroloških radara. Prvi meteorološki radar u Srbiji datira od 1969 godine, u periodu 1970-1978 broj registrovanih oluja je iznosio oko27.000, da bi 1980 godine sa 13 meteoroloških radara Srbija je imala verovatno najgušću mrežu u Evropi (Lit. 9). Radarski podaci su najpre čuvani u formi mikro-filmovanih zapisa planšeta, da bi se kasnije, nabavkom moćnih računara i specijalozovanih sotvera (Ericson RDP i WRDP) obrada i čuvanje podataka u izvanrednoj rezoluciji bili potpuno automatizovani ${ }^{4}$. U okviru Lit.6 je razvijena kompletna, GREED-orijantisana metodologija za analizu radarskih podataka nad slivom i na primeru sliva reke Drine, za koji je izvojeno oko 50 najjačih epizoda, pokazano kako se statistički može analizirati 10 karakteristika jakih kiša. Pored toga, na bazi detaljnih analiza laboratorijskih merenja i simulacije oticaja od prostorno neuniformnih i nestacionarnih (,pokretnih“) kiša (Lit.7) pokazano je da za maksimum oticaja sa sliva usled kratkotrajne jake kiše dinamika kretanja oluje daleko bitnija od ukupne količine pale kiše tokom poplavne epizode. Primer modeliranja poplavnih talasa korišćenjem radarskih podataka opaženih nad slivom reke Kolubare i ILR modela oticaja (S.Jovanović i Z.M.Radić, 1981.) sa koncentrisanim parametrima dat je u (Lit.2), a razrađena je i kompletna metodologija (Lit.8) za predviđanje (blagovremenu najavu) poplavnih talasa na bazi radarskih podataka modelom sa distribuiranim parametrima DILR. Prethodno citirani radovi pokazali su da je dinamika nastanka jakih kiša nad nekim područjem rezultatanta velikog broja faktora. Pri tome neosporno postoje i uticaji orofrafije, ali se oni ne mogu tretirati kao konstantni i na krajnje pojednostavljeni način preko nadmorske visine lokacije od interesa.

Pre ispitivanja karaktera zavisnosti jakih kiša sa nadmorskom visinom interesantno je proveriti i karakter veze prosečnih godišnjih padavina i jakih kiša kraćih trajanja na prostoru Srbije (Slika 3), jer je u nekim drugim regionima utvrđeno da se karakter promena jakih kiša može dovesti u vezu sa prostornim rasporedom prosečnih padavina ${ }^{5}$.

\footnotetext{
${ }^{3}$ Slična se dogodilo i tokom poplave iz Maja 2014. Godine, kasu najveće sume padavina (od 1 do 4 dana) zabeležene na k.s.“Loznica“( $\mathrm{H}=121 \mathrm{mnm})$, a ne na k.s. „Beograd-Vračar“ $(\mathrm{H}=132 \mathrm{mnm})$ ili pak na k.s. „Valjevo“ (H=176 mnm).

${ }^{4}$ Radarska meteorologija u Srbiji je uvedena za potrebe protivgradne zaštite, međutim potencijali su znatno širi, a velike investicije se višestruko mogu isplatiti primenama u hidrološkim modelima za blagovremenu simulaciju i najavu poplava.Nakon 2000 godine radarska mreža je osavremenjena nabavkom kvalitetnijih rada-ra, a postoji i razmena podataka na međunarodnom planu. Na žalost, taj potencijal nije iskorišćen. Naši meteorolozi i hidrolozi bave se „planetarnim problemima“ (globalnim klimatskim promenama) i niko nema interesa za bavljenje ,prizemnim stvarima“ kao što su unapređenja metoda za kvantitativnu prognozu padavina na slivu, analize meteoroloških i hidroloških uslova koji dovode do poplava i uvođenje operativnih modela za najavu poplava na bazi podataka sa meteoroloških radara.

${ }^{5}$ Tako je za prostor Velike Britanije i Irske u okviru meteoroloških analiza koje su sastavni deo čuvene studije FSR (Flood Studies Report, NERC,1975) utvrđeno da se i maksimalni intenziteti 24-časovnih kiša, kao i
} 
International conference

Contemporary achievements in civil engineering 24. April 2015. Subotica, SERBIA
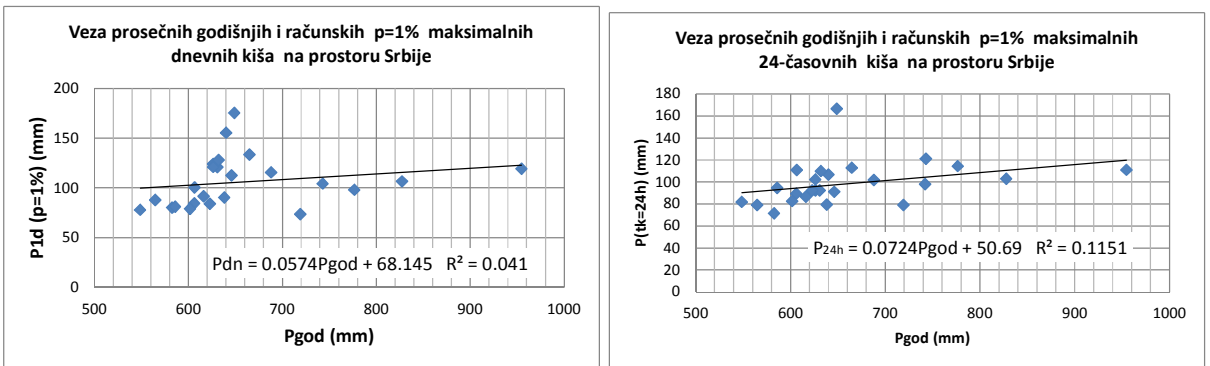

Slika 3. Veza prosečnih godišnjih padavina sa računskim jakim kišama verovatnoće pojave $p=1 \%$ : maksimalnim dnevnim padavinama (levo) i jakim kišama trajanja $24 \mathrm{~h}$ (desno)

Sa Slike 3 se vidi da postoji nagoveštaji tendencije povećanja maksimalnih padavina sa povećanjem prosečnih godišnjih padavina, ali sa velikom disperzijom tačaka i regresionim vezama koje se (mereno koeficijentima determinacije) ne mogu usvojiti za praktične proračune.

Za ekstremne jake kiše verovatnoće pojave $1 \%$ veza padavina sa nadmorskim visinama $\mathrm{i}$ za karakteristična trajanja prikazane su na Slikama 4 i 5.

Na Slici 4, dijagram-levo odnosi se na analize dnevnih maksimuma (podaci sa kišomera), a dijagram-desno na podatke sa pluviografa $(\mathrm{Tk}=1440 \mathrm{~min}=1 \mathrm{~d})$ na istoj lokaciji.
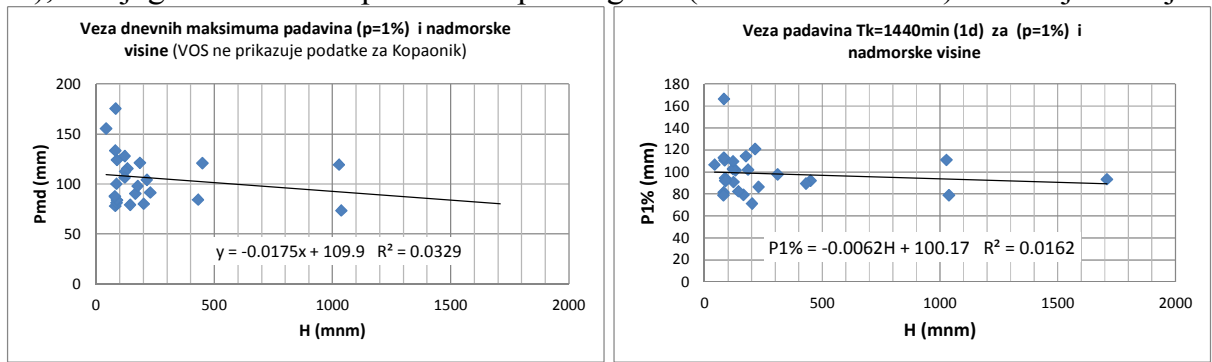

Slika 4. Veze dnevnih maksimuma padavina (levo) i kiša trajanja 1440 min=1dan (desno) sa nadmorskim visinama

Na Slici 5 prikazane su zavisnosti računkskih kiša ( $T=100$ godina) za dva karakteristična trajanja jakih kiša kratkog trajanja $(\mathrm{Tk}=10 \mathrm{~min}$ i $\mathrm{Tk}=60 \mathrm{~min}=1 \mathrm{~h})$, uz napomenu da su iste tendencije dobijene i za ostala anlizirana trajanja (Tk=20 min, $30 \mathrm{~min}, 2 \mathrm{~h}, 3 \mathrm{~h}, 6 \mathrm{~h} \mathrm{i} 12 \mathrm{~h}$ ). 
Међународна конференција

Савремена достигнућа у грађевинарству 24. април 2015. Суботица, СРБИЈА
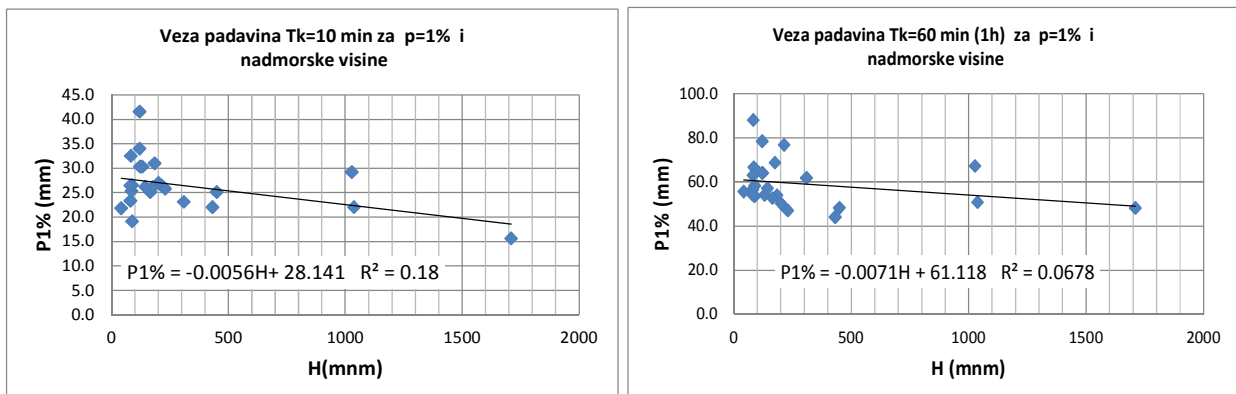

Slika 5. Veze računskih kiša $(p=1 \%)$ jakih kiša kratkog trajanj, $a$ Tk=10 min (levo) $i$ Tk= 60 min=1h (desno), sa nadmorskim visinama

Koeficijenti determinacije su toliko niski da regresione linije nemaju praktičnu primenljivost, ali je indikativno da svi podaci ukazuju na to da postoje indicije opadanje jakih kiša sa nadmorskom visinom (što je suprotno očekivanjima).

Kako je prethodni zaključak donekle iznenađujući, a znajući da vrednosti računskih kiša zavise od usvojene teorijske funkcije raspodele, u nastavku će se veza padavina sa nadmorskom visinom proveriti i na osnovu najvažnijih statistika opaženih (merenih) vrednosti. Ovom analizom obuhvaćena su 9 trajanja kiša (od 10 min do 1440 min=1d), ali se u nastavku prikazuju samo po rezultati za četiri karakteristična trajanja (10min, 1h, 6h, 24h), a podaci se odnose na svih 26 lokacija pluviografa u okviru GMS Srbije.

Za srednje vrednosti jakih kiša kratkih trajanja uočava se trend opadanja za sva trajanja do $12 \mathrm{~h}$ (za koje trend praktično ne postoji), da bi se za trajanje jednodnevnih padavina (1440min) pojavio blagi trend povećanja. Ovo je prikazano na Slici 6.

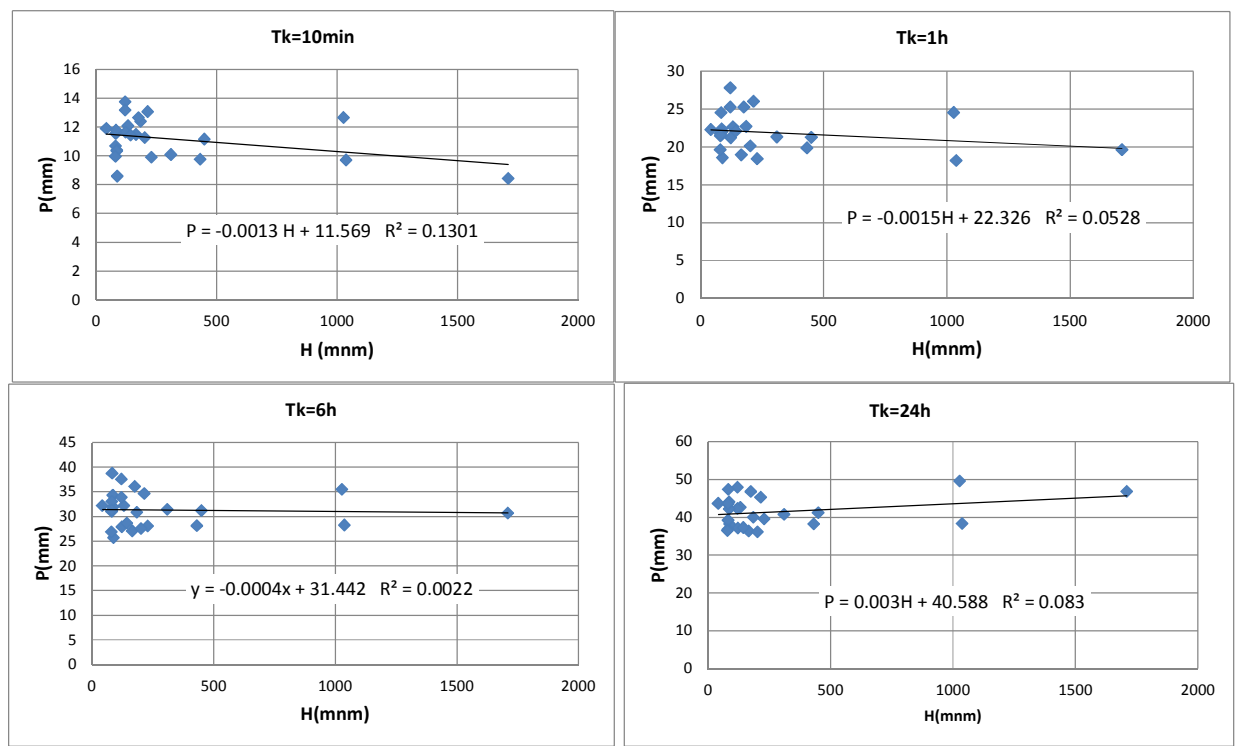

Slika 6. Veze srednjih vrednosti jakih kiša kratkog trajanja sa nadmorskim visinama 
International conference

Contemporary achievements in civil engineering 24. April 2015. Subotica, SERBIA

Za koeficijente varijacije jakih kiša kratkih trajanja (4 reprezentativne vrednosti) analize zavisnosti sa nadmorskim visinama prikazane su na Slici 7. Očigledno je da i ovde absolutno dominiraju negativni trendovi (nema povećanja varijacija sa povećanjem nadmorskih visina).

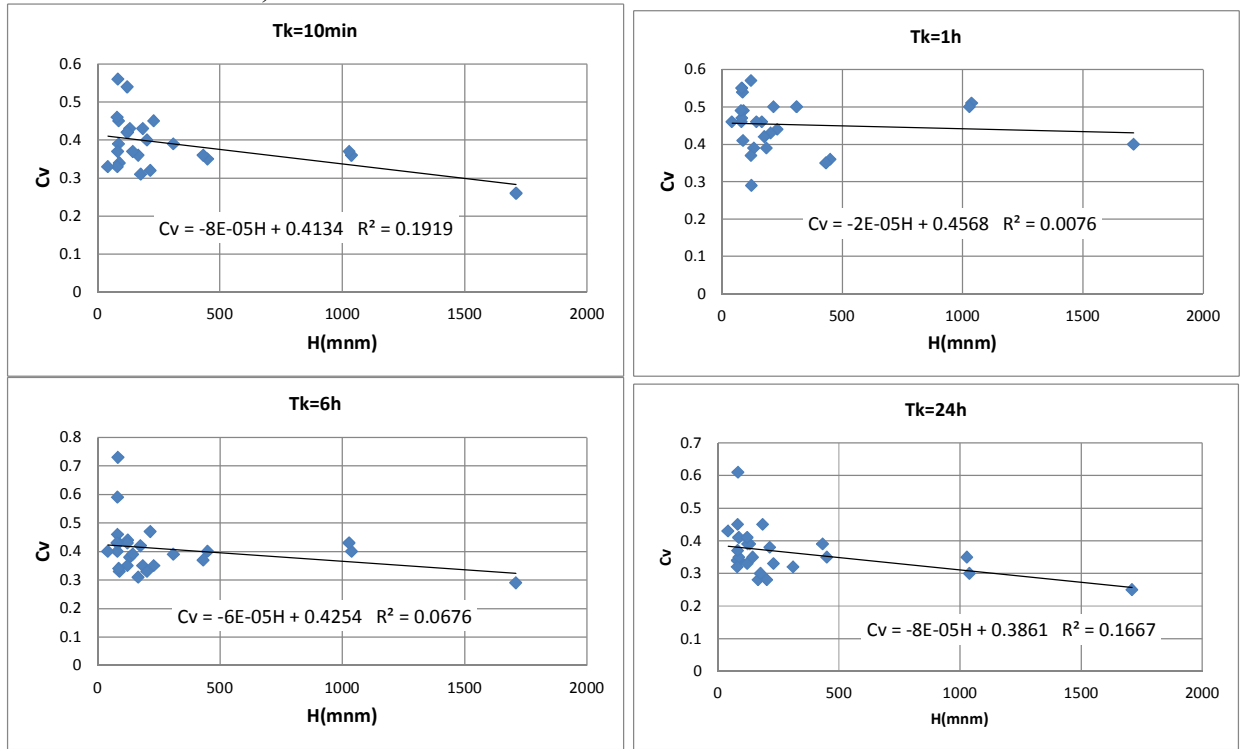

Slika 7. Veze koeficijenata varijacije jakih kiša kratkog trajanja sa nadmorskim visinama

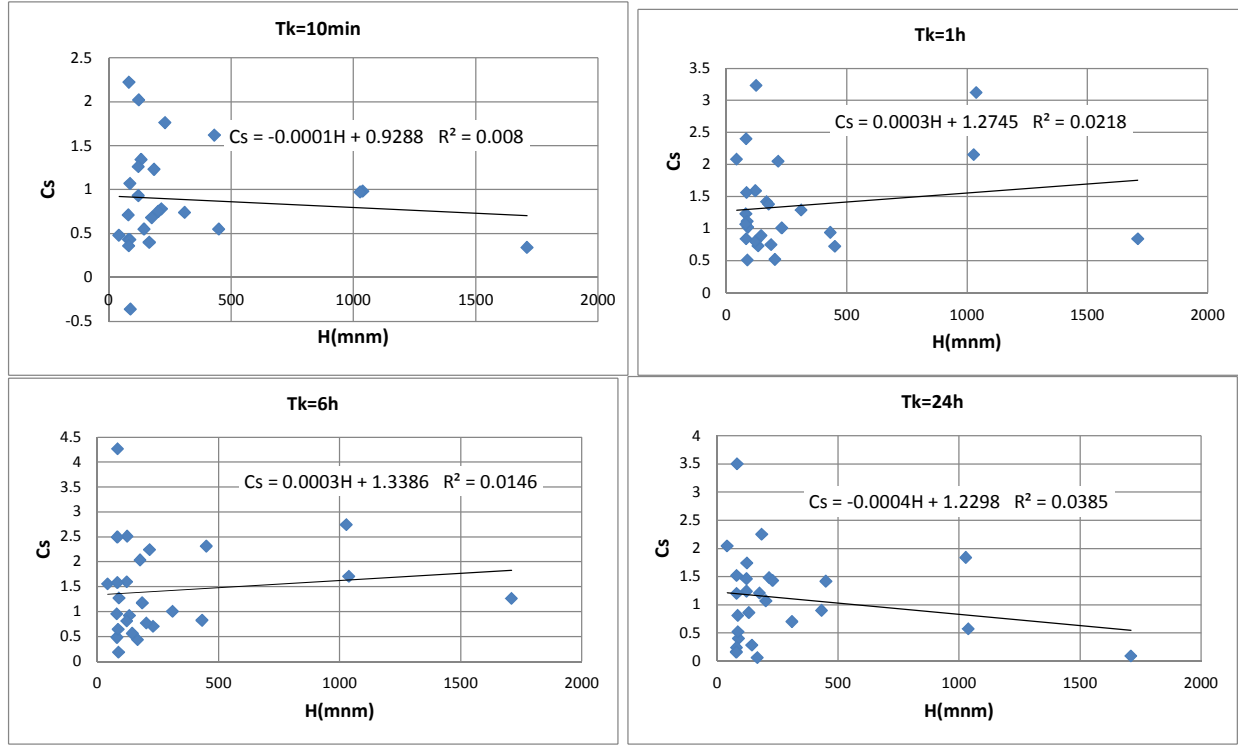

Slika 8. Veze koeficijenata asimetrije jakih kiša kratkog trajanja sa nadmorskim visinama 
Међународна конференција

Савремена достигнућа у грађевинарству 24. април 2015. Суботица, СРБИЈА

\section{ZAKLJUČCI I PREPORUKE}

Analizom podataka sa 26 lokacija GMS koje su uniformno raspoređene po prostoru, a svojim lokacijama verno reprezentuju i zastupljenosti nadmorskih visina kišomera, sa pouzanošću se može zaključiti da ni prosečne, ni računske jake kiše, kao ni statistike jakih kiša kratkog trajanja na prostoru Srbije ne pokazuju zakonomernosti promena u funkciji nadmorskih visina.

Dobijeni rezultati za hidrološku praksu znače da na globalnom planu nema nikakvog opravdanja da se na prostoru Srbije jake kiše koriguju u funkciji nadmorske visine, a da se na lokalnom planu (unutar pojedinih slivova) pre uvođenja bilo kakvih korekcija moraju spovesti dodatne analize na bazi podataka merenih na konkretnom slivu!

$\mathrm{Na}$ prostoru Srbije uzroci nastanka katastrofalnih poplava mogu biti i konvektivne i frontalne kiše. Kod nastanka konvektivnih padavina uticaj orografije može biti izražen ali je kod frontalnih najčešće zanemarljiv. Kišni potencijal je različit za različite tipove oblačnosti, a najveće verovatnoće pojave padavina imaju oblačni sistemi tipa Ns i Cb (nimbo-stratusi i kumulonimbusi). Međutim, na bazi analize 1158 oblačnih sistema i osam tipova oblačnosti (Lit.6) ukupna zastupljenost ova dva tipa oblačnosti je manja od $20 \%$, a zastupljenost $\mathrm{Cb}$ oblačnosti koja je za hidrologe najinteresantnija je svega $6 \%$. Dok se konvektivna oblačnost javlja samo u toplijem delu godine (period Maj-Oktobar), slojasta oblačnost (prem da je najveća učestalost zabeležena u Januaru) može se javiti u bilo kom periodu tokom godine. Ovi podaci pokazuju koliko su važne prostorne analize karakteristika kiša na bazi podataka meteoroloških radara, pa se našim meteorolozima i hidrolozima, u cilju unpređenja zaštite od poplava preporučuje korišćenje informacija koji se nalaze u (neiskorišćenoj) bazi radarskih podataka, i veća posvećenost usavršavanju modela za kvantitativnu prognozu padavina na slivu, analizama meteoroloških i hidroloških uslova koji dovode do poplava i uvođenju operativnih modela za najavu poplava na bazi podataka sa meteoroloških radara. Srbija bi od toga imala veće praktične koristi nego od analiza globalnih klimatskih promena koje nemaju nikakve efekte na svakodnevni život i inženjerske odluke, osim što se (sve česće) koriste kao alibi za katastrofe čije su posledice mogle biti ublažene da se raspolagalo adekvatnim modelima za predviđanja i najave poplava.

\section{ZAHVALNOST}

Rezultati prikazani u ovom radu su deo istraživanja u okviru projekata TR37010 i TR43007 koje finansira Ministarstvo nauke Republike Srbije, kojem se autori ovim putem zahvaljuju na podršci.

\section{ЛИТЕРАТУРА}

[1] Institut za vodoprivredu "Jaroslav Černi" i RHMZS, Vodoprivredna osnova republike Srbije - Hidrološke podloge, Beograd 2009. 
[2] Jovanović,S., Jovanović,M., Radić,M.Z.: The effects of meteorological input on the variability of runoff with time, Proc.of the Hamburg Symp., IAHS Publ.no 140, pp375-385, Hamburg 1983

[3] Petrović,J., Radić,M.Z.: Uticaj topografije na prostornu strukturu padavina u slivu reke Drine, Vodoprivreda 147-149, str.45-53, Beograd, 1994.

[4] Prohaska,S., Bartoš-Divac,V. i dr.: Intenziteti jakih kiša u Srbiji, Istitut za vodoprivredu ,Jaroslav Černi“, Beograd, 2014.

[5] Radić, M.Z.(editor): Nagle poplave -uzroci i posledice, JDH i JKMHP,Zbornik radova sa savetovanja JUSOP'89 Kopaonik 19-21.12.1988, SHMZ, Beograd 1989.

[6] Radić,M.Z.,Milinković,M.,Šakota,V.: Analiza radarskih podataka opažanja padavina nad slivom, str.222-228, , Nagle poplave - uzroci i posledice, JDH i JKMHP,Zbornik radova sa savetovanja JUSOP'89 Kopaonik 19-21.12.1988, SHMZ, Beograd 1989.

[7] Radić,M.Z.(doktorska disertacija):Modeliranje oticaja za stacionarne i nestacionarne kiše na bazi podataka sa laboratorijskih slivova, Građevinski fakultet, Beograd, 1989.

[8] Radić,M.Z., Petrović,J.: Modeliranje oticaja za pokretne kiše, str.229-235 , Nagle poplave - uzroci $i$ posledice, JDH i JKMHP,Zbornik radova sa savetovanja JUSOP'89 Kopaonik 19-21.12.1988, SHMZ, Beograd 1989.

[9] Radić,M.Z.: Application of weather radar in mountainous basins, p.284-290 in FRIEND (Flow Regimes from International Experimental and Network Data, Third report: 1994-1997, UNESCO, IHP (Phases IV and V), Cemagred Edition, Paris 1997

\section{IFLUENCES OF ELEVATIONS ON PRECIPITATIONS IN SERBIA}

Summary: Analyses of ellevations influences on precipitations in Serbia are based on data from 26 pluviometrique stations, and 437 rain-gauges. Influences are studied for yearly averages, maximal daily data, and heavy rain durations from 10 minutes to 24 hours. For heavy rains elevation influences on main statistics (averages, coefficient of variations and skewness) and design rains (return period 100 years) are analysed.

It is shown that range of elevations in Serbia is not wide, so other factors (as the stocastic rain characteristics) are predominant. It is sugested that avalilable metheorological radars data must be detailed studies and used in hydrological practice for the improuvement of precipitations prediction and real-time floods forecasting in Serbia.

Keywords: Hydrology, rainfall, regional analyses 